\title{
Empowerment group of Farmer's wife to reduce the Pesticide Toxicity
}

\author{
Eka Lestari Mahyuni $^{1 *}$, Puteri Chairani Eyanoer ${ }^{2}$, Erna Mutiara ${ }^{3}$, Arfah Mardiana Lubis ${ }^{1}$, Isyatun \\ Mardhiah Syahri ${ }^{1}$
}

${ }^{1}$ Department of Occupational Safety and Health Faculty of Public Health University of North Sumatra

${ }^{2}$ Department of Community Medicine Faculty of Medicine University of North Sumatra ${ }^{3}$ Department of Biostatistics and Population, Faculty of Public Health USU

*Email: e79mahyuni@gmail.com

\begin{abstract}
Community empowerment is the one of efforts that undertaken as part of the health promotion which aimed to improve public health. In general, one of the phenomena of society which are expected to consume vegetables and fruits in balance quantity and quality. Consumption of vegetables and fruits also become the second destination health measures of GERMAS (Gerakan Masyarakat Sehat). Karo is an area that is synonymous with the world of agriculture and many farming communities are vulnerable to disease because of exposure to the working environment, either physical or chemical. The farming community is also almost no health care and more oriented to produce in optimum. In addition, there are many groups that still nonproductive and can be developed, one group of wives of farmers. The solution given in service activities to produce the healthy food like a salad of vegetables and fruits with antioxidant power, antisianin and other nutrients that protect and maintain the farmer's health from several symptoms of illness due to consumption patterns and patterns of work at risk. Devotion done by brainstorming methods, training and demonstration of manufacture of the product with the target groups of farmers wife. Outcomes targeted is a food product healthy namely Salad Pelangi as food is beneficial to balance the body, nourish and protect the health of the body as well as foods that have anti venom and avoid hypertension, heart disease, diabetes, cancer and chemical effects of occupational risks as farmers. Other outcomes in the form of a scientific article and video activities. The content of Salad Pelangi are choosen from the fruits and vegetable that has the rainbow colour such as tomato, carrot, orange, avocado, jelly, yam, and purple cabbage. All of these has the antioxidant function that could be reduce the pesticide toxicity.
\end{abstract}

Keyword: farmer's wife, horticulture, health, food, salad

\section{INTRODUCTION}

Improving the health community as the purpose of health development could be done by various methods, including through the empowerment of communities to create an independent community, prosperous and productive (Sulaeman, 2012; Mardikanto, T., \& Soebiato, 2017). Community empowerment is a strategy that encapsulates the social values and represents a new paradigm in development to meet the basic needs of a society (Mardikanto, 2010; Theresia, A., Andini,

K. S., Nugraha, P. G., \& Mardikanto, 2015).

The agricultural sector is an area of business that produce natural and consump resources for public, but also had a few dilemmas and problems that need to be improved. On the other hand, agricultural development is inseparable from the pesticides use, especially in horticultural crops, because this plant is very susceptible to pests. Intensification of the pesticide use is increasing exposure and poisoning for agricultural labor in particular pesticide sprayers(Sukmawati and Maharani IP, 2004), According to (Munawir, 2005; Sinulingga, 2006;

Karyadi, 2008; Khozanah, 2010). Improper of pesticides use that harmfull for farmers and consumers, nontarget microorganisms and impact on the soil and water environment pollution.

Karo is the one of plateau that dominates the world of agriculture, especially horticulture crops. One of the most rural area of horticultural farms (vegetables and fruits) is Sumber Mufakat village. Horticultural crops that are managed in this village such as flowers, tomatoes, cauliflower, broccoli, peppers, carrots, potatoes and beans. Vegetables and fruits are the source of vitamins, minerals, and dietary fiber that act as antioxidants and prevent cell damage (Kementerian Kesehatan Republik Indonesia, 2016).

Consumption of vegetables and fruits are quite a role in maintaining normaly of blood pressure, blood sugar and blood cholesterol and reduce the risk difficult defecation and obesity. Consumption of vegetables and 
fruits are quite a role in the prevention of chronic non-communicable diseases (Kementerian Kesehatan Republik Indonesia, 2018).

Decreading of consumption fruit and vegetables in Indonesia was inadequate. Based on statistic data (Badan Pusat Statistik, 2016) Indonesian population to consume vegetables and fruits as much as 173 grams per day less than the Nutrition Adequacy Score (AKG) recommended that as many as 400 grams per capita per day. Further, not all of Indonesia's population consume vegetables and fruit, as much as $97.3 \% 73.6 \%$ consume vegetables and fruit consumption in 2016. Consumption of fruit decreased less in the amount of 3.5\%, while vegetables decreased by 5.3\%. kangkung, spinach and beans is the most consumed vegetable in 2016. As for fruit, the most widely consumed are bananas, oranges and rambutan.

Over the last 5 years, precisely in 2016, a decline in fruit and vegetable consumption. The decline is greatest in agricultural household good group for fruit consumption amounted to $-10.58 \%$ (55 grams per capita per day and vegetables amounted to $-14.03 \%$ (111 grams per capita per day, while for other industrial sectors there is an increased consumption of vegetables by $8,51 \%$ (113 grams per capita per day and fruits by $6.92 \%$ (73 grams per capita per day). this illustrates the food intake of the farmers do not qualify good nutrition, especially vegetables and fruits, because of spending to get their daily needs done once in a week, which in terms of society called the "weekend."(Marsaulina and Arlinda, 2007; Badan Meteorologi Klimatologi dan Geofisika (BMKG), 2017),

One effort that can be done is to raise awareness of the importance of eating

\section{METHODS}

Community service activities, especially farmers wives group horticultural farmers in the Sumber Mufakat village done in three phases of activity. In the first stage begins with advocating with the leader of village and community the wife. Further dissemination of interventions to be done as a community service activities.

The next stage of the wives of farmers who also helped and role in agricultural processes is collected and trained. The training activities manufacture "Salad Pelangi" will be started with the wife of farmer's perception through health education materials about Salad Pelangi maker and the resulting health benefits by eating processed food. Education is given by using presentations and live demonstrations. The presentation provided include assessment of efficacy or benefit of any vegetables and fruits that exist that are high in fiber and antioxidants that can lower toxicity is assumed widely experienced in horticultural farmers in the village of Sumber Mufakat.

The Salad Pelangi making production process is:

a. Prepare a salad of raw materials which has seven colors

b. Choosing a salad of raw materials according to the complaint and material benefits

c. Peeling and salad processing in accordance with the aesthetics and usability salad

d. Presenting salad produced in good packaging and closed

e. Consuming salad and or market salad on the target group

The products that have been processed will be promoted and marketed

together in order to improve the economy of farmers and the use of local resources. Promotion can be done through the local markets, online, and social media.

\section{RESULT AND DISCUSSION}

Community service activities in the scheme shall serve lecturer has been done, especially in the group of wives horticultural farmers in the village of the Sumber Mufakat Kabanjahe. As an initial step, advocating with the village chief and several key persons in the village Sumber Mufakat . In this advocacy activities will be pursued creation of agreement and unity of perception management of local resources which manifested itself in the community empowerment activities to be carried out as a community service activities. Consensus in this activity is supported by the Village Head Sumber Mufakat and integrated into the activities of the community who care poisoning due to the use of pesticides. 


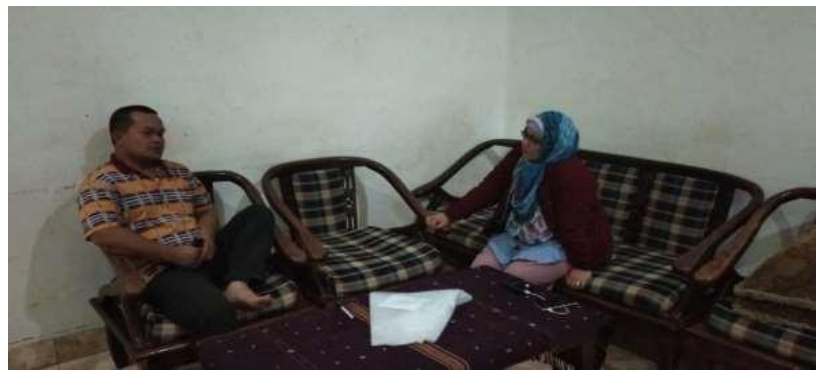

Figure 3. 1. Audience with the Village Head

In general, the farmer's wife in the village Sumber Mufakat also helps in managing the farm or agricultural land. Therefore the empowerment program presented in this Salad Pelangi-making activities provide significant benefits in improving family health and reducing the risk of pesticide poisoning. poisoning

Making the Salad Pelangi with a farmer's wife targeted service activities aimed at reducing the risk of due to the use pestisda. Therefore, the raw material salad rainbow, or fruits and vegetables that have been selected are fruits and vegetables that have efficacy as an antioxidant, preventing cancer and has an appeal through color which drafted following the colors of the rainbow: red, orange, yellow, green, blue, indigo and violet.

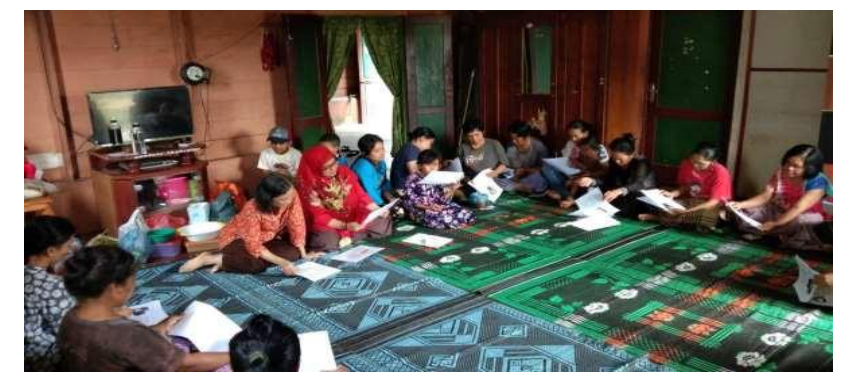

Figure 3.2. Submission of material to the Group Salad Pelangi Farmer Wife

Therefore, training is done as perception in empowerment activities throughout the wives of farmers educated on Salad Pelangi of raw material selection. Education is given simply where adapted to local conditions. The training activities and the manufacture of the Salad Pelangi performed on the same day and are located in one of the farmhouses. Use simple materials given training through "card" that contains fruits and vegetables are used as material of Salad Pelangi. Each card contains material on selected fruits and vegetables along with the content, the efficacy and benefits.

The Salad Pelangi of raw materials

are:

1. Tomato, to meet the red color. Tomatoes are rich in vitamins A, K, B1, B5, B3, B6, B7 and C. The red color in tomatoes contain lycopene, a powerful antioxidant that can fight disease and anti-cancer (8 Manfaat Tomat untuk Tubuh, 2017; Tomat, 2019),

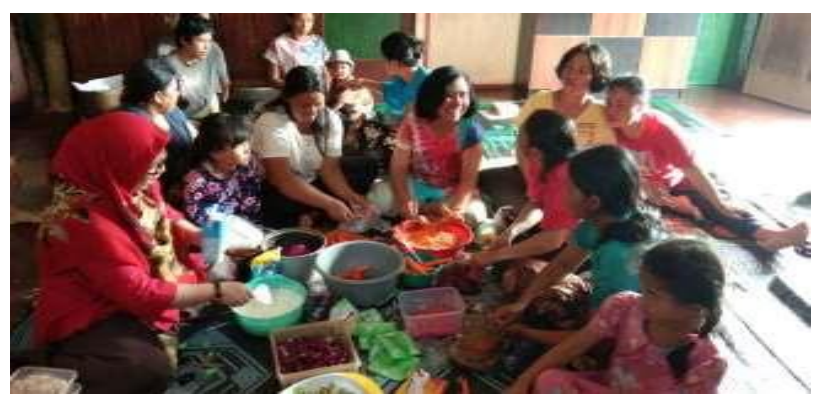

Figure 3.3. Group Salad Pelangi Farmer Wife 
2. Carrots, to meet the color orange. In addition to vitamin A, carrots also contain vitamins B1, B2, B3, B6, B9, C. Carrots also contain calcium, iron, magnesium, phosphorus, potassium, and sodium. As an antioxidant carrots contain alpha carotene, beta carotene, and polyacetylenes lycopene (Wortel, 2016; Ardini, 2018),

3. Orange, yellow color represents. Citrus fruits contain phytochemicals that fight cancer-causing agents. Oranges contain a flavonoid called hesperidin which naturally makes the blood pressure under control. Oranges also contain limonene as a cancer inhibitor. Oranges as antioxidants can protect against heart disease and against virus infection because it is rich in polyphenols and vitamin $\mathrm{C}$ to maintain immunity (JawaPos, 2017; Jeruk, 2019).

4. Avocado, to meet the color green. Avocados contain a source of fat and contain potassium as well as act as a high fiber and contribute to weight loss, reducing blood sugar spikes, and is strongly associated with a lower risk of many diseases. Besides, avocados also serves to absorb nutrients by adding avocado to a salad or avocado oil can increase the absorption of antioxidants of 2.6 to 15 times. So, avocados can improve the nutritional value of other plant-based foods. It makes one reason to enter source of healthy fats while eating vegetables (Avokad, 2019; Yunita, 2019),

5. Nutrijell is one equivalent of a Salad Pelangi of raw material that replaces the blue color of the rainbow because there are no fruits or vegetables that are blue. Jelly contains a lot of benefits such as natural amino acids that are good for the skin. Jelly also help digestion and the production of collagen. Efficacy jelly assist them in the process of cell regeneration and helps maintain an ideal body weight. Jelly is rich in carbohydrates and B vitamins that help boost immunity. As a source of folic acid, which helps maintain healthy hair. natural gelatin which helps improve lubrication of joints and prevent arthritic conditions in women. helps reduce skin disorders such as skin redness (rosacea) and acne (Prasasty, 2012),

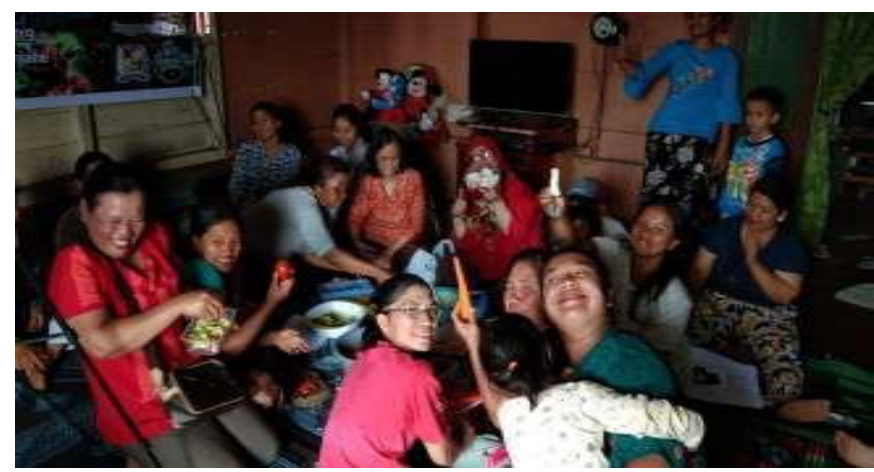

Figure 3.4. Submission of Group Salad Pelangi Farmer Wife

6. Yam, In a rainbow of colors are indigo color. To meet this color was replaced with a water content of benefit to support the efficacy of other fruits and vegetables that are used in the processing of salad rainbow. Fruit is chosen to replace the color indigo is the fruit of yam. Yam also contain dietary fiber, vitamin C, vitamin E, folic acid, vitamin B6, pantothenic acid, potassium, magnesium, manganese, copper, iron, and a small amount of vegetable protein. Therefore, the yam has many benefits including helping the digestive process and impact both for constipation, flatulence, diarrhea, indigestion up lainnya.Pada amount of 100 grams of yam, already contained $40 \%$ of the daily dose of vitamin C in the body (Manfaat Bengkoang, Si Umbi Putih yang Kaya Serat, 2012; Bengkuang, 2019),

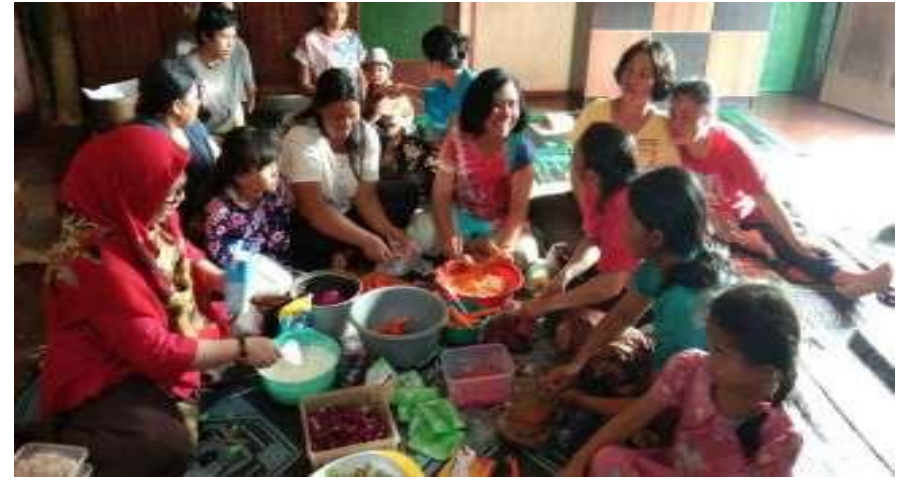

Figure 3.5. Submission of material 
7. Purple cabbage, purple cabbage merupakn variant of cabbage that diproduk of agricultural engineering and purple. Purple cabbage is rich in vitamin $\mathrm{C}$, an important antioxidant that plays a role in strengthening the immune system as it contains Vitamin major role in cancer prevention. It was due to the high levels of antioxidants such as indoles and anthocyanins in dalamnya.mengandung magnesium, manganese, calcium and other essential minerals and vitamins such as vitamin

$\mathrm{K}$. These vegetables are rich in vitamin B complex which helps in the proper functioning of the metabolism in cells. if you suffer from hyperthyroidism is recommended that you avoid the consumption of purple cabbage. because it is the cruciferous vegetables are known to affect the thyroid gland (Setyorini, 2018),

Making the Salad Pelangi with all of that done by live demonstration. The preferred process of making the salad dressing that will be sprinkled on fruit and vegetable pieces selected. As for making mayonasise done by mixing mayonnaise and milk. to 250 grams of mayonnaise ready to be mixed with 100 liters of liquid milk and stir evenly and serve as the Salad Pelangi dressing. Salad Pelangi already ready to be consumed and is expected to improve health and prevent the risk of exposure to pesticides is a perceived direct exposure of farmers every day.

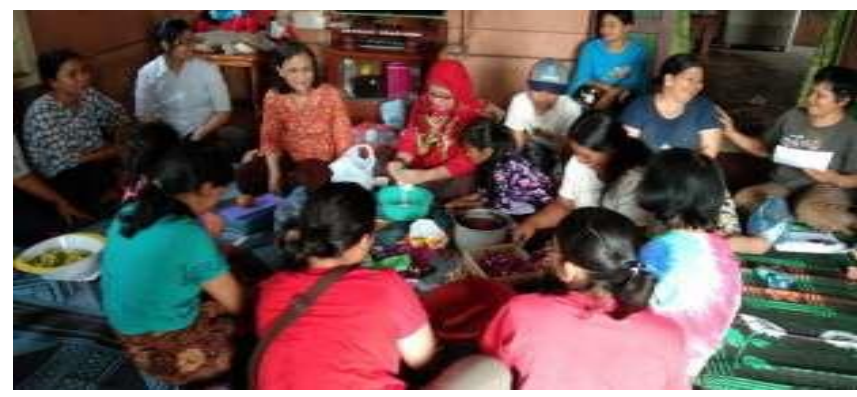

Figure 3.6. Process Salad Pelangi

Salad Pelangi-making activities as community empowerment can be received well by the public. Wives of farmers who have been trained and manufacture of Salad Pelangi also realize that for farmers just sell raw materials as a crop. Farmers never process to produce feedstock that is widely available in the village to be increased to prosuk which has a high ekopnomi value. With the education, training and coaching manufacture Salad Pelangi, farmer's wife has a new job with marketing products as an icon Salad Pelangi prevention of poisoning due to the use of chemicals, namely pesticides.

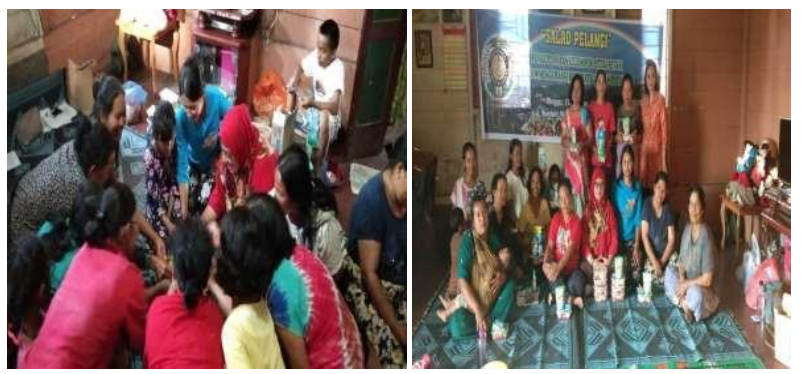

Figure 3.7. Together with the Society Photos

\section{KESIMPULAN (CONCLUSION)}

Based on the results of community service activities can be concluded that the group of wives of farmers have the potential to be empowered in favor of reducing the risk of poisoning due to the use of chemicals such as pesticides. Making the Salad Pelangi is one of empowerment efforts in the field of nutrition improvement in efforts to change consumption behavior eat more healthy and nutritious, wherein each of the efficacy of the content of the fruits and vegetables that are used to reduce the risk of cancer or poisoning in the body. 


\section{UCAPAN TERIMAKASIH (ACKNOWLEDGMENTS)}

We said thank you for Mr. Seven Nov Sinukaban as leader of Seven HAMLET OF Sumber Mufakat Village that has suppot this activity to solve the pesticide problem. We also say thank you for all of farmer's wife withthe attendance and interesting in Salad Pelangi effort to reducing the pesticide toxicity. We hope the empowerment to create the healthy food in Salad Pelangi could be continued in daily and increase the economic of farmer and sustain in good and supported marketing of product.

\section{DAFTAR PUSTAKA (REFERENCES)}

Ardini, W . (2018) 7 Manfaat Menakjubkan Jus Wortel, Selain untuk Kesehatan Mata.

Badan Meteorologi Klimatologi dan Geofisika (BMKG) (2017) 'Special Focus: Fruit and Vegatables Consumption and Production Trends’, Food Security Monitoring Bulletin Indonesia,

Badan Pusat Statistik (2016) Konsumsi Sayur dan Buah Susenas Maret 2016.

JawaPos (2017) Raih 10 Manfaat Hebat dari Konsumsi Buah Jeruk. Available

Karyadi (2008) 'Dampak Penggunaan Pupuk dan Pestisida yang Berlebihan terhadap Kandungan Residu tanah pertanian Bawang Merah di Kecamatan Gemun Kabupaten Kendal', Agromedia, 26(1), pp. 10 - 19.

Kementerian Kesehatan Republik Indonesia (2016) Rencana Aksi Kegiatan Pusat Analisis Determinan Kesehatan 2016-2019. Jakarta: Pusat Analisis Determinan Kesehatan.

Kementerian Kesehatan Republik Indonesia (2018) Entaskan Kemiskinan Desa, Kementerian Pertanian Canangkan Program Bekerja.

Khozanah, M. (2010) 'PESTISIDA ORGANOKLORIN DI PERAIRAN TELUK KLABAT-PULAU BANGKA', Oseanologi dan Limnologi di Indonesia, 36(1), pp. 1 - 19.

Manfaat Bengkoang, Si Umbi Putih yang Kaya Serat (2012).

Mardikanto, T., \& Soebiato, P. (2017) Pemberdayaan masyarakat dalam perspektif kebijakan publik. Bandung: CV. Alfabeta.

Marsaulina, I. and Arlinda, S. . (2007) 'Faktor-Faktor yang Berhubungan dengan Keracunan Pestisida pada Petani Hortikultura di Kecamatan Jorlang Hataran Kabupaten Simalungun Tahun 2015', Media Litbang Kesehatan, 17(1), p. 23.

Munawir, K. (2005) 'Pemantauan Kadar Pestisida Organoklorin di Beberapa Muara Sungai di Perairan Teluk Jakarta’, Oseanol. Limnol. Indonesia, 37, pp. 13-23.

Prasasty, R. . (2012) Manfaat Jelly yang Belum Anda Tahu.

Setyanti, C. . (2017) Tujuh Inovasi Makanan Sehat Selama 2017.

Setyorini, T. (2018) 7 Manfaat Kol Ungu bagi Kesehatan dan Kebugaran

Sinulingga (2006) 'Telaah Residu Organoklor pada Wortel (Dacus carota L.) di Kawasan Sentra Kab. Karo Sumut', Jurnal Sistem Teknik Industri, 7(1), pp. 92-97.

Sukmawati, A. and Maharani IP, A. (2004) 'Hubungan Antara Perilaku dalam Pengelolaan Pestisida dengan Aktivitas Enzim Cholinesterase Darah pada Petani Cabe di Desa Santana Mekar Kecamatan Cisayong Kabupaten Tasikmalaya', Jurnal Ekologi Kesehatan, pp. 80-89. 
Eka Lestari et.al Empowerment group of

Sulaeman, E. S. (2012) Pemberdayaan Masyarakat Di Bidang Kesehatan, Teori dan Implementasi. Yogyakarta: Gadjah Mada University Press.

Theresia, A., Andini, K. S., Nugraha, P. G., \& Mardikanto, T. (2015) Pembangunan Berbasis Masyarakat. Bandung: CV. Alfabeta.

Yunita, N.W. (2019) 9 Manfaat Alpukat untuk Kesehatan, Kamu Bisa Makan Setiap Hari. 